Article

\title{
Petrological and Geochemical Properties of Greek Carbonate Stones, Associated with Their Physico-Mechanical and Aesthetic Characteristics
}

\author{
Ioanna Badouna ${ }^{1, *}$, Petros Koutsovitis ${ }^{2}(0)$, Christos Karkalis ${ }^{1,3}$, Konstantinos Laskaridis 4 , \\ Nikolaos Koukouzas ${ }^{1}$, Pavlos Tyrologou ${ }^{1} \oplus$, Michalis Patronis ${ }^{4}$, Christos Papatrechas ${ }^{4}$ \\ and Petros Petrounias ${ }^{2}$ (I) \\ 1 Centre for Research and Technology, Hellas (CERTH), 52 Egialias, Marousi, GR-15125 Marousi-Athens, \\ Greece; karkalis@certh.gr (C.K.); koukouzas@certh.gr (N.K.); tyrologou@certh.gr (P.T.) \\ 2 Department of Geology, Section of Earth Materials, University of Patras, GR-26504 Patras, Greece; \\ pkoutsovitis@upatras.gr (P.K.); Geo.plan@outlook.com (P.P.) \\ 3 Department of Mineralogy and Petrology, Faculty of Geology and Geoenvironment, \\ National and Kapodistrian University of Athens, Panepistimioupoli Zografou, GR-15784 Athens, Greece \\ 4 Hellenic Survey for Geology and Mineral Exploration, Spirou Louis 1, Olympic Village Acharnae, \\ GR-13677 Athens, Greece; laskaridis@igme.gr (K.L.); patronis@igme.gr (M.P.); \\ papatrechas@widowslive.com (C.P.) \\ * Correspondence: badouna@certh.gr; Tel.: +30-6972557912
}

Received: 27 April 2020; Accepted: 28 May 2020; Published: 31 May 2020

\begin{abstract}
Greece is considered amongst the world's top marble producers in the global carbonate ornamental stone market. Selected Greek carbonate ornamental stones considered in our study suite are characterized by their distinctive and in some cases unique appearance, having a significant impact on their commercial value. Their wide range of colour varieties and their physico-mechanical properties are closely related to their mineral assemblage, chemical constitution, petrographic properties, structural defects, which in turn depend highly upon their metamorphic/diagenetic grade and in some cases hydrothermal processes that affected them. This study endeavors to feature the petrographic, mineralogical and geochemical properties of the main Greek carbonate ornamental stones from selected localities and their by-product waste material used as aggregates. The documented data aims to serve a better understanding of the dynamic Greek marble industry by relating their mineral and chemical properties with their physico-mechanical and aesthetic characteristics.
\end{abstract}

Keywords: marbles; aggregates; physico-mechanical properties; mineralogy; geochemistry

\section{Introduction}

Ornamental stone production in Greece is an important industrial sector, significantly contributing to its economy. Greece ranks in the world's top 10 natural stone producers both in size of production and exports, alongside China, India, Iran, Turkey, Italy, Spain, Brazil, Egypt and Portugal. Ornamental stones are exported to several countries in the form of slabs, tiles and blocks [1-4], having a high economic impact and industrial value in the construction industry. During the last years exports have been boosted, with more than $50 \%$ of the country's marble production being exported. Decorative carbonate block mining for the period 1980-2006 was estimated at 13 million tons [2,5]. Their contribution to the Greek economy, especially in the last decade, is highly notable exhibiting an increase in production of $44.4 \%$ between the years 2007 and 2014 [6]. Ninety-four percent of the aggregates produced were derived from primary resources, comprising mainly of crushed rock aggregates due to the existence 
of good quality carbonate deposits. From 2009 to 2018, Greece's quantity of marble blocks and slabs exports moved up by a massive $232.38 \%$, ranking third in Europe after Italy and Turkey [7]. The number of small, medium-sized and also a few large-sized companies engaged in the Greek marble sector are estimated to be about 4000 and employ more than 60,000 people. Further growth of the industry in the near future will depend on new investments, market flexibility, competitive prices and further increase of the links to European Union (EU) markets and penetration in other emerging economies.

The selection of a rock as a building material is determined by its aesthetic characteristics and its physico-mechanical properties [8]. The Greek carbonate stone products are characterized by their high quality, diversity, and are prized for decorative and sculptural uses [9]. It has been used from small to iconic works around the world, including the Mecca shrine, the Shanghai Opera House and the Barcelona airport, (white marble of Thassos), the building of French State Television, the Grand Tasmanian Abu Dhabi, the parliaments of several former Soviet republics (Volakas marble), as well as the famous Reflection towers in Singapore (Ariston Drama marble). Their uniqueness is strongly correlated with their aesthetic characteristics that have a significant impact on their market price [10-13]. The aesthetic characteristics are highly dependent upon factors that include: (a) color variability (b) mineral assemblage, (c) petrographic textural features, (d) grain size, (e) modal composition and (f) degree of metamorphism and/or metasomatism, deformation and schistocity. The wide range of colour varieties reflects the wide variability of their mineral composition, degree of recrystallization and the presence of impurities likely associated with secondary hydrothermal activity [14]. Their structural defects mainly include discontinuities that can either be empty cavities or filled with compact and loose materials that alter their appearance and mechanical integrity. The petrographic characteristics of rocks affect their macro-mechanical properties. Mineral composition, grain size and microstructure are the most important parameters to influence rock strength and deformability [15].

Carbonate rock quarrying industry generates large quantities of waste products in coarse and powder form that raise the necessity for environmentally friendly and sustainable reuse through recycling applications. Their use as aggregates or cement replacing materials poses health, environmental and financial benefits [16,17]. Aggregates used in concrete, have a profound effect upon the cement physical and mechanical properties $[18,19]$. It is highly beneficial to address the characteristics of aggregate to be used within the concrete mix, as these will define its workability, strength and durability properties. The porosity of aggregates and their water absorption has an impact on the bonds between the aggregate and the cement paste, whereas strength and abrasion resistance characteristics of aggregates has a positive impact upon the quality of the concrete [20-22]. Mineralogical and mechanical properties of marble by-products also display a significant influence on their behavior when used in road construction, brick ceramics and landfills [21].

Despite their significance in applications, the ornamental carbonate rocks mined in Greece and their resulting aggregates have been given little attention in the scientific literature for their aesthetic and mechanical characteristics. To the best of our knowledge there is very limited information available on correlations between the marble petrography and their mechanical properties.

The present study focuses on investigating and highlighting the physico-mechanical properties associated with the aesthetic features of characteristic Greek ornamental carbonate rocks by correlating them with their compositional and textural properties. Results and findings of this research paper are expected to contribute to the cement industry, by offering information to use for the selection of the proper aggregate for concrete mixtures. For this purpose, we present detailed petrographic, mineralogical, whole-rock chemistry data and physico-mechanical test results from characteristic carbonate rocks used as ornamental stones and aggregates from operating mines in selected localities in Greece.

\section{Materials and Methods}

Our study suite consists of 73 commercial carbonate samples that comprise: 26 calcitic marbles, 5 impure «cipollino» marbles, 15 dolomitic marbles, 21 limestones and 6 dolomites (Table 1: 
Average whole-rock chemistry results and standard deviation; Supplementary Table S1: whole-rock chemistry results of 73 samples). These have been examined so as to determine their petrographic, mineralogical and geochemical properties. Calcitic marble samples were selected from the regions of Western Macedonia (Kozani), Eastern Macedonia (Kavala, Drama, and Thessaloniki), Central Greece (Magnesia, Evia island), North Aegean (island of Thassos), South Aegean (islands of Naxos and Paros) and Peloponnese (Lakonia) (Figure 1). Cipollino marbles were chosen from the regions of Epirus (Arta, Thesprotia) and Central Greece (Magnesia, Evia island). Dolomitic marbles were selected from Eastern Macedonia (Kavala, Drama), Peloponnese (Argolis) and North Aegean (island of Thassos). Limestone samples were chosen from the regions of Epirus (Ioannina), Central Greece (Viotia, Etoloakarnania, Evia island), Peloponnese (Argolis), North Aegean (island of Chios) and South Aegean (island of Crete), whereas dolomites were derived from Central Greece (Viotia), Peloponnese (Argolis) and North Aegean (island of Skyros).

Table 1. Average whole rock major elements (wt. $\%) \pm(1 \sigma)$ and trace elements (ppm) compositions (from Table S1) of 73 carbonate ornamental stone samples from selected regions in Greece.

\begin{tabular}{|c|c|c|c|c|c|c|c|c|c|c|}
\hline \multirow[t]{2}{*}{$\begin{array}{c}\text { Rock Type } \\
\text { (n: Number of Samples) }\end{array}$} & \multicolumn{2}{|c|}{$\begin{array}{l}\text { Calcitic Marbles } \\
\text { (n: 26) }\end{array}$} & \multicolumn{2}{|c|}{$\begin{array}{l}\text { Cipollino Marbles } \\
\text { (n: 5) }\end{array}$} & \multicolumn{2}{|c|}{$\begin{array}{l}\text { Dolomitic Marbles } \\
\text { (n: 15) }\end{array}$} & \multicolumn{2}{|c|}{$\begin{array}{l}\text { Limestones } \\
\text { (n: 21) }\end{array}$} & \multicolumn{2}{|c|}{$\begin{array}{l}\text { Dolomites } \\
\quad(\mathrm{n}: 6)\end{array}$} \\
\hline & Avg. & $\pm(1 \sigma)$ & Avg. & $\pm(1 \sigma)$ & Avg. & $\pm(1 \sigma)$ & Avg. & $\pm(1 \sigma)$ & Avg. & $\pm(1 \sigma)$ \\
\hline $\mathrm{SiO}_{2}$ & 1.10 & 3.66 & 4.89 & 1.27 & 0.09 & 0.14 & 2.50 & 6.28 & 0.32 & 0.32 \\
\hline $\mathrm{TiO}_{2}$ & 0.02 & 0.02 & 0.05 & 0.05 & 0.01 & 0.01 & 0.04 & 0.08 & 0.02 & 0.04 \\
\hline $\mathrm{Al}_{2} \mathrm{O}_{3}$ & 0.27 & 0.58 & 1.01 & 0.26 & 0.04 & 0.10 & 0.34 & 0.42 & 0.05 & 0.04 \\
\hline $\mathrm{Fe}_{2} \mathrm{O}_{3} \mathrm{t}$ & 0.10 & 0.18 & 0.73 & 0.27 & 0.02 & 0.03 & 0.31 & 0.77 & 0.17 & 0.16 \\
\hline $\mathrm{MnO}$ & 0.01 & 0.02 & 0.06 & 0.02 & 0.00 & 0.01 & 0.04 & 0.11 & 0.01 & 0.02 \\
\hline $\mathrm{MgO}$ & 1.07 & 1.08 & 0.90 & 0.31 & 19.38 & 1.90 & 1.04 & 0.67 & 18.80 & 1.15 \\
\hline $\mathrm{CaO}$ & 53.66 & 2.66 & 50.92 & 1.68 & 33.35 & 2.59 & 52.10 & 4.86 & 34.23 & 2.18 \\
\hline $\mathrm{Na}_{2} \mathrm{O}$ & 0.32 & 0.36 & 0.30 & 0.52 & 0.22 & 0.29 & 0.37 & 0.43 & 0.70 & 0.66 \\
\hline $\mathrm{K}_{2} \mathrm{O}$ & 0.11 & 0.16 & 0.11 & 0.18 & 0.05 & 0.07 & 0.15 & 0.33 & 0.12 & 0.14 \\
\hline LOI & 42.63 & 1.87 & 40.52 & 0.87 & 45.79 & 0.78 & 41.97 & 3.49 & 45.74 & 1.14 \\
\hline Total & 99.26 & 0.72 & 99.50 & 0.57 & 98.95 & 0.66 & 98.86 & 1.01 & 100.14 & 0.55 \\
\hline $\mathrm{V}$ & 2.81 & 5.72 & 10.00 & 3.39 & 1.48 & 2.29 & 7.06 & 15.77 & 2.87 & 1.53 \\
\hline $\mathrm{Cr}$ & 37.55 & 109.24 & 78.00 & 121.33 & 43.14 & 88.38 & 26.71 & 29.97 & 25.00 & 5.93 \\
\hline Co & 2.39 & 1.13 & 6.30 & 2.80 & 2.14 & 1.27 & 3.39 & 2.38 & 2.48 & 0.88 \\
\hline $\mathrm{Ni}$ & 22.30 & 47.06 & 53.60 & 52.43 & 21.07 & 42.03 & 21.52 & 21.30 & 16.00 & 6.16 \\
\hline $\mathrm{Cu}$ & 5.59 & 4.32 & 40.20 & 36.85 & 4.99 & 4.38 & 7.79 & 6.51 & 12.50 & 14.28 \\
\hline $\mathrm{Zn}$ & 22.35 & 11.37 & 29.40 & 10.16 & 18.50 & 9.15 & 27.43 & 13.78 & 27.00 & 13.75 \\
\hline As & 4.48 & 6.91 & 2.28 & 1.06 & 2.51 & 2.63 & 16.33 & 57.49 & 63.58 & 150.12 \\
\hline $\mathrm{Sr}$ & 152.65 & 63.22 & 475.20 & 60.62 & 60.21 & 49.09 & 342.38 & 229.18 & 131.50 & 99.07 \\
\hline $\mathrm{Cd}$ & 0.43 & 0.45 & 0.53 & 0.05 & 0.60 & 0.29 & 0.44 & 0.37 & 8.63 & 19.78 \\
\hline $\mathrm{Ba}$ & 129.22 & 327.59 & 75.80 & 12.42 & 365.38 & 1276.68 & 279.00 & 899.93 & 1027.33 & 2436.25 \\
\hline $\mathrm{Pb}$ & 8.22 & 10.49 & 9.30 & 2.33 & 14.06 & 21.70 & 8.63 & 3.56 & 7.55 & 5.84 \\
\hline $\mathrm{Be}$ & 0.43 & 0.92 & 0.25 & 0.06 & 0.98 & 1.78 & 0.31 & 0.43 & 0.77 & 0.69 \\
\hline $\mathrm{Rb}$ & 13.54 & 37.56 & 7.90 & 1.75 & 3.66 & 6.98 & 11.18 & 23.07 & 5.45 & 8.08 \\
\hline $\mathrm{Bi}$ & 0.04 & 0.12 & 0.05 & 0.06 & 0.17 & 0.53 & 0.10 & 0.27 & 0.37 & 0.80 \\
\hline $\mathrm{U}$ & 0.56 & 1.22 & 0.52 & 0.64 & 0.26 & 0.32 & 1.11 & 0.92 & 1.28 & 1.75 \\
\hline Sc & 19.76 & 13.66 & 11.80 & 11.58 & 13.56 & 11.75 & 14.91 & 12.86 & 13.28 & 15.61 \\
\hline $\mathrm{Y}$ & 2.78 & 2.21 & 4.20 & 1.02 & 1.71 & 1.41 & 3.53 & 2.87 & 2.90 & 3.51 \\
\hline Th & 0.72 & 0.83 & 1.08 & 0.18 & 0.60 & 0.71 & 0.57 & 0.64 & 1.45 & 1.56 \\
\hline $\mathrm{Sb}$ & 1.19 & 1.27 & 1.10 & 0.46 & 0.87 & 1.07 & 1.18 & 1.16 & 0.58 & 0.41 \\
\hline $\mathrm{Ta}$ & 4.68 & 16.48 & 0.30 & 0.08 & 1.27 & 1.51 & 1.09 & 1.13 & 0.93 & 0.58 \\
\hline $\mathrm{Nb}$ & 5.09 & 11.03 & 1.18 & 0.75 & 1.43 & 1.20 & 1.59 & 0.96 & 1.25 & 1.08 \\
\hline
\end{tabular}

Notes: Total iron as $\mathrm{Fe}_{2} \mathrm{O}_{3} \mathrm{t}$, LOI is loss on ignition.

Petrographic thin sections were examined using a Zeiss Axioskop-40 with a Jenoptik ProgRes CF Scan microscope camera at the Laboratories of the Center for Research and Technology, Hellas (CERTH), Attica, Greece. Other analyses and measurements were performed at the Hellenic Survey for Geology and Mineral Exploration, Attica, Greece. Particularly, mineral chemical analyses were conducted using scanning electron microscopy with energy-dispersive X-ray spectroscopy (SEM-EDS, JEOL JSM-5600 scanning electron microscope, equipped with an automated energy dispersive analysis system ISIS 300 OXFORD, with the following operating conditions: $20 \mathrm{kV}$ accelerating voltage, $0.5 \mathrm{nA}$ beam current, 20s time of measurement and $5 \mu \mathrm{m}$ beam diameter. XRD analyses were conducted using a Philips X'Pert Panalytical X-ray diffractometer (XRD), operating with $\mathrm{Cu}$ radiation at $40 \mathrm{kV}, 30 \mathrm{~mA}, 0.020$ step size and $1.0 \mathrm{sec}$ step time. For the evaluation of the XRD patterns we used DIFFRAC plus EVA 
software v.11 (Bruker-AXS, Billerica, MA, USA) based on the ICDD Powder Diffraction File (2006). In order to determine their mineralogical assemblages, we performed detailed petrography coupled with XRD profile patterns. Accessory mineral phases that did not exceed $1 \mathrm{wt} . \%$, were identified with the use of petrographic and scanning electron microscope facilities; hence these mineral phases display very small peaks in the XRD spectrums and thus cannot be detected with this method.

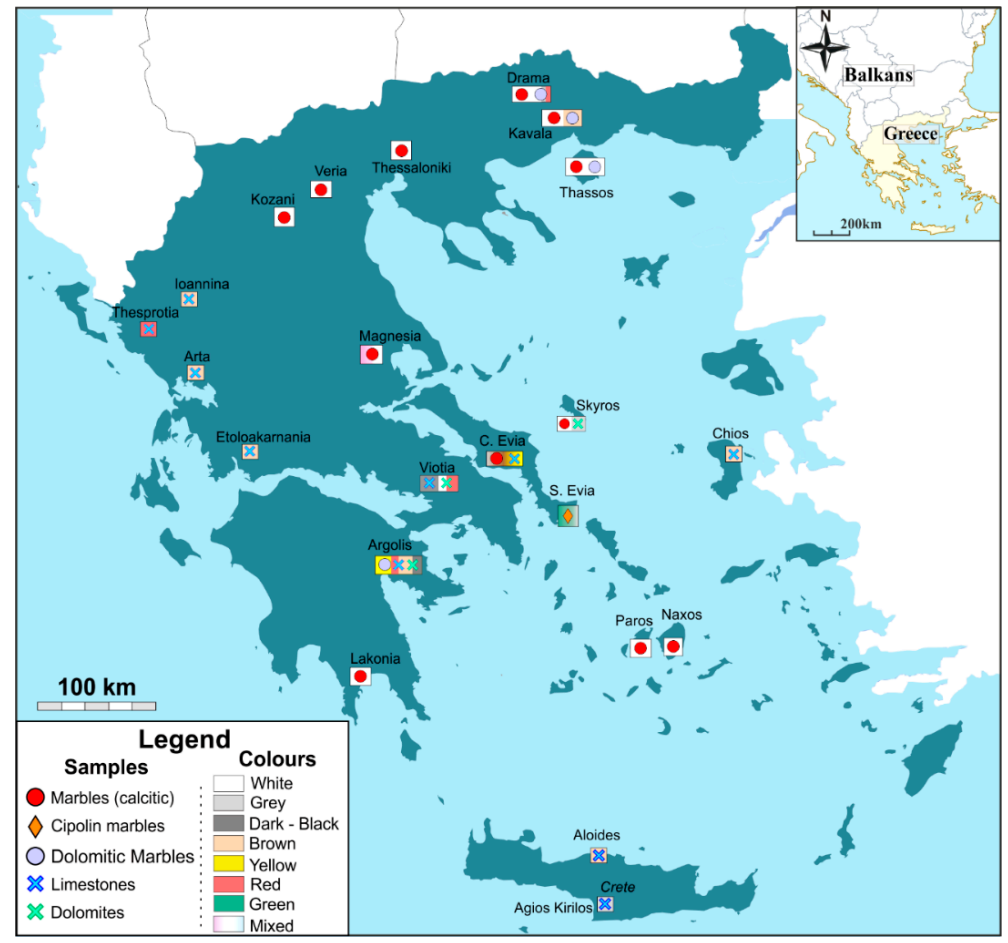

Figure 1. Map of Greece indicating the sample localities.

Whole rock geochemical analyses for major elements were carried out using a Panalytical PW-2400 wavelength $X$-ray fluorescence analyzer, equipped with Rh-tube. The process followed before analyses was oven-drying of samples, grinding to a fine powder in a Fritsch motorized mill and then formed to fuse beads. Trace elements analyses were carried out with inductively coupled plasma-atomic emission spectroscopy (ICP-MS) after pulverizing to $<200$ mesh in an agate mill part of the grinded samples and digesting with a mixture of $\mathrm{HCl}-\mathrm{HNO}_{3}-\mathrm{HF}$ acids.

To distinguish calcite from dolomite in our rock samples with the carbonate staining method, we applied alizarin red upon thin sections. The solution was produced by mixing $0.2 \%$ alizarin red [sodium alizarin sulphonate $=\mathrm{CO} \cdot \mathrm{C}_{6} \mathrm{H}_{4} \cdot \mathrm{CO} \cdot \mathrm{C}_{6} \mathrm{H} \cdot(\mathrm{OH})_{2} \mathrm{SO}_{3} \cdot \mathrm{Na}+\mathrm{H}_{2} \mathrm{O}$ ] with $0.2 \% \mathrm{HCl}$. Thin sections were soaked in the solution for about $1 \mathrm{~min}$. After the test the samples were washed with distilled water. This resulted in changing the colour of calcite to red, while dolomite becomes pale blue.

The physico-mechanical studies of the ornamental stone samples were conducted at the LITHOS Laboratory of the Hellenic Survey for Geology and Mineral Exploration. The testing methods were conducted according to EN Standards and shown in Supplementary Table S2. In particular, the following physicomechanical tests were performed: (1) Apparent density (kg/m³) (EN1936:2006) [23]; (2) Open porosity (vol.\%) (EN1936:2006) [23]; (3) Water absorption at atmospheric pressure (wt.\%) (EN13755:2005) [24]; (4) Uniaxial compressive strength (MPa) (EN1926:2006) [25]; (5) Flexural strength under concentrated load (MPa) (EN12372:2006) [26]; (6) Breaking load at dowel hole (N) (EN13364:2002) [27]; (7) Abrasion resistance ( $\mathrm{mm}^{3}$ —loss in volume) (EN14157:2017-method B) [28]; (8) Rupture energy (J) (EN14158:2004) [29]; (9) Frost resistance (MPa-tested after 48 frost resistance cycles) (EN12371:2010 and EN12372:2006) [26,30]. 


\section{Results}

\subsection{Petrography-Mineralogy}

Greek carbonate rocks from our study suite include marbles, limestones and dolomites. The examination of marble thin sections reveals that the aforementioned can be distinguished into typical calcitic, dolomitic and impure «cipollino» marbles, having been affected by metamorphic and/or metasomatic/hydrothermal processes (applies to the case of cipollino marbles). In particular, calcitic marbles mainly consist of calcite (77-100 vol.\%), with less frequent or even absent dolomite (0-23 vol.\%). Accessory mineral phases include opaque Fe-Mn and Fe-Cr oxides (magnetite, hematite, chromite), barite, clay minerals, phyllosilicate minerals (muscovite, biotite and sericite) (Figure 2f), albite, quartz and epidote. They often display heteroblastic textured calcite with dentate boundaries (Figure 2a). Very fine grained homogenous rock types display well developed equilibrium textures, which in some cases are cross-cut by a network of Fe-oxide veins, whereas coarse-grained types are composed of alternating layers of limpid calcite, clay minerals and turbid dolomite. Crystal elongation as well as different grain size and orientation often create the appearance of veins (Figure 2c) and laminae (Figure 2b).

Impure "cipollino» marbles (or Cipollino Verde) [31] are considered as a unique variety of calcitic marbles. They mainly consist of calcite (78-87 vol.\%), as well as of an additional metasomatic assemblage (up to 18 vol.\%) that includes epidote, pumpellyite, chlorite and quartz (Figure 2e,f). Accessory minerals comprise Fe-oxides (mainly ilmenite, scarce magnetite and/or hematite), muscovite, chromite (Figure 3c), biotite, sphene, rutile, apatite, zircon and tourmaline. Their texture is characterized as crystalloblastic to heteroblastic and locally lepidoblastic with a visible preferred orientation of the metasomatic-associated minerals. Cipollino marbles are fine or coarse grained, often being cross-cut by large (250-300 $\mu \mathrm{m}$ thick) carbonate veins and thinner stylolites. Calcite can either appear as large-sized $(300 \mu \mathrm{m})$ slightly deformed hypidiomorphic phenocrysts (Figures 2e and 3a) or as part of the fine grained groundmass (Figure 3c). Highly deformed and foliated cipollino marbles have a well-developed schistocity, consisting of alternating layers of hypidiomorphic calcite crystals and metasomatic chlorite, epidote, biotite and fish-shaped muscovite phenocrysts (Figures 2e and 3a) as a result of deformation phenomena. These rocks are often accompanied by carbonate-chlorite schists (not included in our study suite), which differ from cipollino marbles in having a higher chlorite/calcite ratio.

Dolomitic marble samples are either characterized by their balanced calcite/dolomite ratio or consist almost exclusively of dolomite (calcite 3-37 vol.\%; dolomite 63-97 vol.\%). In both cases accessory minerals include opaque Fe-oxides, fluorite, sphalerite, apatite (Figure 3b), chromite, quartz, chlorite and muscovite. They present homoblastic medium to coarse-grained textures consisting of allotriomorphic to hypidiomorphic dolomite and calcite crystals with dentate boundaries. In a few samples the texture of the matrix is sparitic or micritic, while in some cases matrix is cross-cut by calcite veins (Figure $2 \mathrm{~d}$ ).

The non-metamorphic Greek carbonate rocks comprise limestones and less often dolomites [32]. Limestones consist almost exclusively of calcite (90-98 vol.\%), with minor and variable amounts of dolomite (2-10 vol.\%). Calcite either appears as idiomorphic to hypidiomorphic grains (Figure 2b) or in the form of sparitic aggregates within the groundmass. Accessory minerals include clay minerals, quartz, apatite and opaque Fe-Mn and Fe-Cr oxides. Gastropod fossils and bioclasts were occasionally identified and in cases replaced by the Fe-Mn-Cr oxides in the form of magnetite and/or chromite. The limestones display a variety of textural features most often being crystalline, clastic, granular or massive. The matrix of these rocks in most cases ranges from microsparitic to sparitic. Secondary calcite-rich veins and stylolites cross-cut the fabric as a result of organic matter dissolution (Figure 2g). 

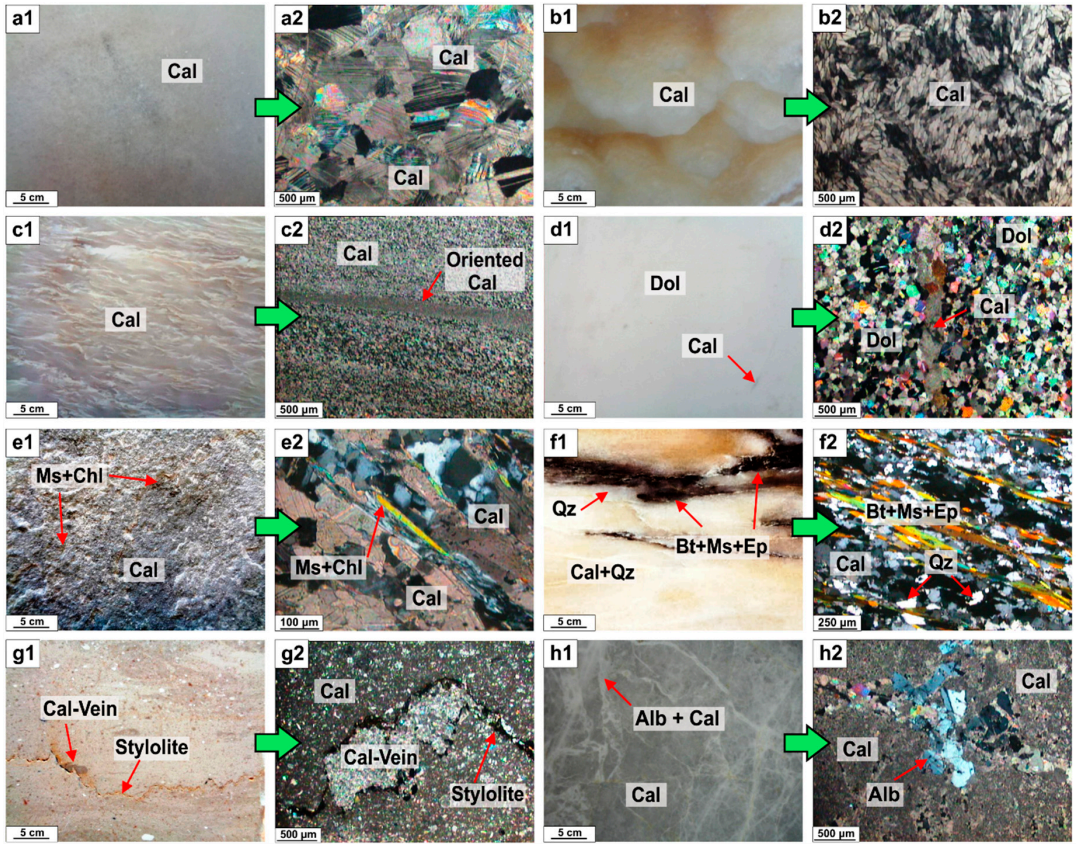

Figure 2. Macroscopic images and crossed polars photomicrographs ( 1 and 2 respectively) (a) Calcitic marble sample KM_1 composed of hypidiomorphic calcite (Cal) crystals. (b) The "crinkled" structure of alabaster calcitic marble STE_12 composed of elongated anisotropic calcite (Cal) crystals gathering in groups with different orientation. (c) Calcitic marble sample TH-3 composed of oriented calcite (Cal) crystals of different grain size. (d) Dolomitic marble sample AM_19 in which calcite (Cal) occurs in veins within a dolomite (Dol) rich groundmass. (e) Cipollino marble sample TH-6 including calcite (Cal) crystals along with muscovite (Ms), chlorite (Chl) and quartz (Qtz) (f) Calcitic marble sample TH-2 including calcite (Cal) crystals along with muscovite (Ms). (g) Limestone sample H_7 including secondary calcite veins (Cal) and stylolites. (h) Dolomite sample STE_1 consisting of dolomitic (Dol) groundmass and veins of secondary material filled with calcite (Cal) and albite (Alb).
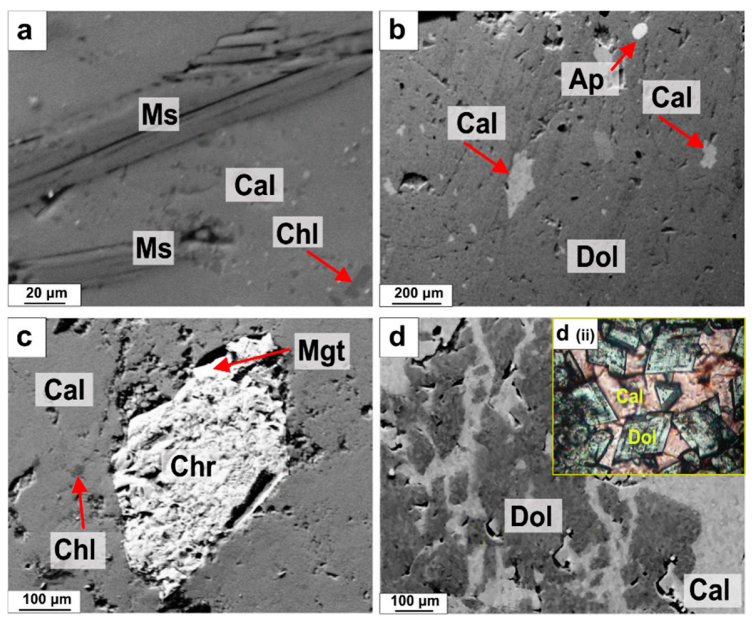

Figure 3. Back-Scattered images of marble samples. (a) Muscovite (Ms) and chlorite (Chl) crystals developed within a calcite groundmass (cipollino marble sample STE_11); (b) Calcite crystal (Cal) and apatite (Ap) within the dolomitic (Dol) rich groundmass (dolomitic marble AM_3); (c) Chromite (Chr) altered to magnetite within a calcitic (Cal) rich groundmass of cipollino marble TH-6; (d) Dolomitic rock (sample STE_14) that includes both dolomite (Dol) and calcite (Cal) intergrown crystals. f(ii). Inserted photomicrograph of the same dolomitic rock sample (sample STE_14), in which alizarin red was applied upon a thin section. Red colour shows calcite crystals, whereas pale blue the dolomite crystals. 
Dolomites mainly consist of micritic and grain dolomite (81-94 vol.\%), with relatively smaller amounts of calcite (6-19 vol.\%) (Figure 3d). These rocks appear as very fine grained or cryptocrystalline. Accessory minerals include quartz, feldspars and Fe-Mn opaque oxides. Dolomites display massive heteroblastic textures consisting of microsparitic to sparitic dolomite. Their matrix is often cross-cut by secondary veins, whereas fractures and cavities are often filled with sparitic calcite and albite (0.002 to $0.5 \mathrm{~mm}$ sized) (Figure 2h).

\subsection{Geochemistry}

The petrographic examination of this study suite identified five specific types of carbonate rock that include: calcitic marbles, impure cipollino marbles, dolomitic marbles, limestones and dolomites. Their whole-rock geochemical composition and in particular their $\mathrm{CaO} / \mathrm{MgO}$ ratio can be used to distinguish these rocks into two main types, regardless of their metamorphic and/or metasomatic degree [33]. Thus, calcitic marbles, impure cipollino marbles and limestones are classified as calciocarbonatites, whereas dolomitic marbles and dolomites are magnesiocarbonatites. As noticed from the ternary discrimination plot of Figure 4, both types are considered as Fe-poor, with calciocarbonates displaying higher $\mathrm{CaO}$ and lower loss on ignition (LOI) contents compared to the magnesiocarbonates. Based upon the ternary plot of Figure 4, both calcitic as well as dolomitic metamorphic and non-metamorphic samples present a linear $\mathrm{SiO}_{2}$ increase, regardless of their $\mathrm{CaO} / \mathrm{LOI}$ ratio values, which remain relatively constant. The highest $\mathrm{SiO}_{2}$ contents are noticed in the cipollino marbles, as well as in a few of the limestone samples.

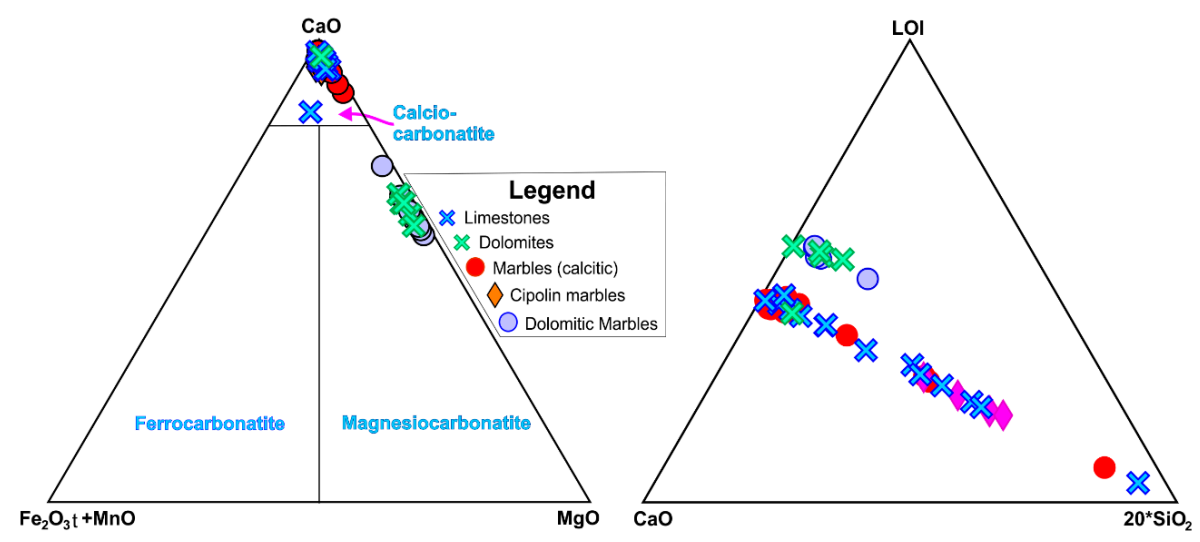

Figure 4. Ternary discrimination diagram of carbonated samples in the fields of calciocarbonatite, ferrocarbonatite and magnesiocarbonatite (left). Ternary $\mathrm{CaO}-20 * \mathrm{SiO}_{2}-\mathrm{LOI}$ diagram depicting the relationship between the $\mathrm{SiO}_{2}$ content and the $\mathrm{CaO} / \mathrm{LOI}$ ratio (right). Green square: limestone, pink circle: marble; blue triangle: dolomite. (after Woolley and Kempe, 1989 [31]).

In particular, calcitic marbles present high $\mathrm{CaO}$ and low $\mathrm{MgO}$ contents (49.86-55.85 wt.\% and 0.00-5.11 wt.\% respectively), whereas LOI contents range from 40.22 to $44.50 \mathrm{wt}$ \%. Total alkali values are regarded as low $\left(\mathrm{Na}_{2} \mathrm{O}+\mathrm{K}_{2} \mathrm{O}: 0.02-1.60\right) . \mathrm{SiO}_{2}, \mathrm{Al}_{2} \mathrm{O}_{3}$ and $\mathrm{Fe}_{2} \mathrm{O}_{3}$ t contents are considerably low $\left(\mathrm{SiO}_{2}<0.40\right.$ wt.\%; $\mathrm{Al}_{2} \mathrm{O}_{3}<0.10$ wt.\%; $\mathrm{Fe}_{2} \mathrm{O}_{3} \mathrm{t}<0.80$ wt.\%). Exception to the above is the silica bearing calcitic marble from Crete island, with a relatively high content of $\mathrm{SiO}_{2}$ (18.60), the white marbles of Attiki (2.95 and $1.20 \mathrm{wt} . \%$ ) and the light red marble of Magnesia (3.10 wt.\%). Cr and Ni contents (4-36 ppm and 6-29 ppm, respectively) are low, except for a sample from the Thessaly region with significantly higher $\mathrm{Cr}$ and $\mathrm{Ni}$ contents (537 ppm and $237 \mathrm{ppm}$, respectively). Ba and Sr contents range rather significantly from (17-1600 ppm and 70-340 ppm, respectively), whereas $\mathrm{V}$ and As contents (0.00-24 ppm and 1.00-32 ppm, respectively) can be considered as low.

Impure cipollino marbles exhibit high $\mathrm{CaO}$ and low $\mathrm{MgO}$ contents ( $\mathrm{CaO}: 48.05-52.12$ wt.\% and MgO: 0.71-1.45 wt.\%), with lower LOI contents (39.42-41.65 wt.\%) and similar total alkali values $\left(\mathrm{Na}_{2} \mathrm{O}\right.$ $+\mathrm{K}_{2} \mathrm{O}: 0.06-1.66$ ) compared to those of calcitic marbles. $\mathrm{SiO}_{2}, \mathrm{Al}_{2} \mathrm{O}_{3}$ and $\mathrm{Fe}_{2} \mathrm{O}_{3}$ t contents (3.00-6.05 wt.\%, 
0.73-1.40 wt.\% and 0.45-1.17 wt.\%) are the highest compared to all other carbonate rock samples from our study suite. $\mathrm{Cr}$ and $\mathrm{Ni}$ values (20-26 ppm and 25-36 ppm, respectively) are similar to those measured in calcitic marbles. Interestingly, a sample from the region of Thessaly displays high $\mathrm{Cr}$ and Ni contents (295 ppm and $147 \mathrm{ppm}$, respectively), a case similar to that noticed in the aforementioned calcitic marble sample from the same region. These values are clearly associated with the presence of chromite. Ba, As and V contents (56.00-90.00 ppm, 1.40-4.00 ppm and 6.00-15.00 ppm, respectively) are lower compared to those measured in calcitic marbles, whereas Sr contents (426.00-570.00 ppm) are higher.

Dolomitic marbles present higher $\mathrm{MgO}$ and LOI, as well as lower $\mathrm{CaO}$ contents (14.42-21.98 wt.\%, $43.50-46.95 \mathrm{wt} . \%$ and 30.90-41.37 wt.\%, respectively) compared to those of calcitic marbles. Their total alkali values $\left(\mathrm{Na}_{2} \mathrm{O}+\mathrm{K}_{2} \mathrm{O}: 0.02-1.37\right)$ are highly comparable with the calcitic marble varieties. Based on their $\mathrm{CaO} / \mathrm{MgO}$ ratio values, the vast majority of dolomitic marbles cannot be regarded as purely dolomitic, since calcite and subsequently $\mathrm{CaO}$ contents are preserved. In most cases $\mathrm{SiO}_{2}, \mathrm{Al}_{2} \mathrm{O}_{3}$ and $\mathrm{Fe}_{2} \mathrm{O}_{3} \mathrm{t}$ contents are lower compared to those of calcitic marbles $\left(\mathrm{SiO}_{2}<0.40 \mathrm{wt} . \% ; \mathrm{Al}_{2} \mathrm{O}_{3}<0.40 \mathrm{wt}\right.$.\%; $\left.\mathrm{Fe}_{2} \mathrm{O}_{3} \mathrm{t}<0.10 \mathrm{wt} . \%\right)$. Cr and Ni contents (6-29 ppm and 5.5-25 ppm, respectively) are highly comparable to those of calcitic marbles, except for one sample from Peloponnese with significantly higher values (sample P-9; Table S1). Ba, Sr, As and V contents (0.0-95.0 ppm, 16-127 ppm, 0.6-6.0 ppm and $0.0-9.0 \mathrm{ppm}$ respectively) are lower than those of calcitic marbles. The exception is the dolomitic marble from Skyros with significantly higher contents of Ba (4800 ppm) and Sr (190 ppm).

Limestones present high $\mathrm{CaO}$ and very low $\mathrm{MgO}$ contents (50.05-55.44 wt.\% and 0.05-2.25 wt.\% respectively), whereas LOI contents range from 39.33 to $44.90 \mathrm{wt} . \%$. In most limestone samples $\mathrm{SiO}_{2}, \mathrm{Al}_{2} \mathrm{O}_{3}$ and $\mathrm{Fe}_{2} \mathrm{O}_{3} \mathrm{t}$ contents are low $\left(\mathrm{SiO}_{2}<0.85\right.$ wt.\%; $\mathrm{Al}_{2} \mathrm{O}_{3}<0.89$ wt.\%; $\mathrm{Fe}_{2} \mathrm{O}_{3} \mathrm{t}<0.51$ wt.\%). However, some samples have higher $\mathrm{SiO}_{2}$ contents (1.65-5.05 wt.\%), attributed to the occurrence of quartz and feldspars, especially at the silica bearing black limestone from Central Macedonia (28.95 wt.\%). Cr and Ni contents (3-116 ppm and 8-100 ppm, respectively) are rather variable, whose values depend upon the presence or absence of chromite. Ba and Sr contents (18-220 ppm and 85-925 ppm, respectively) are considered as quite high, whereas V and As contents ( $0-75.0 \mathrm{ppm}$ and 1.0-9.0 ppm, respectively) are regarded as low. Significantly higher contents of Ba and As are presented at the brown limestone of Crete island (4200 ppm and 267 ppm, respectively).

Dolomites present higher $\mathrm{MgO}$ and LOI, as well as lower $\mathrm{CaO}$ contents (17.64-20.20 wt.\%, $44.20-46.95$ and 31.60-37.54 wt.\%, respectively) compared to those of limestones. Total alkali contents range from 0.13 to $2.13 \mathrm{wt} . \%$, whereas $\mathrm{SiO}_{2}, \mathrm{Al}_{2} \mathrm{O}_{3}$ and $\mathrm{Fe}_{2} \mathrm{O}_{3}$ t contents are considered as being very low $\left(\mathrm{SiO}_{2}<0.85\right.$ wt.\%; $\mathrm{Al}_{2} \mathrm{O}_{3}<0.10$ wt. $\% ; \mathrm{Fe}_{2} \mathrm{O}_{3} \mathrm{t}<0.42$ wt.\%). $\mathrm{Cr}, \mathrm{Ni}$, Ba and $\mathrm{Sr}$ contents (15.00-30.00 pm, 9.00-24.00 ppm, 5-72 ppm and 20-251 ppm, respectively) are lower compared to those observed in limestones, whereas $\mathrm{V}$ and As contents (1.1-5.0 and 0.9-4.0 wt.\%, respectively) are slightly lower. The exception is the grey dolomite of Evia with significantly higher contents of $\mathrm{Ba}$ and As (6000 ppm and $370 \mathrm{ppm}$, respectively).

\subsection{Physico-Mechanical Tests}

The physico-mechanical results determined from tests conducted on samples from our study suite (as described in Chapter 2) are shown in Supplementary Table S2. In particular, regarding the apparent density values, the lowest correspond to limestones from Crete $\left(2030 \mathrm{~kg} / \mathrm{m}^{3}\right)$ and the highest $\left(2830-2840 \mathrm{~kg} / \mathrm{m}^{3}\right)$ from calcitic marbles in Skyros, as well as dolomitic marbles from Thassos and Drama. The lowest open porosity values $(0.2-0.3 \%$ vol.) have been measured in some of the calcitic marbles (Thassos, Kozani, Veria), limestones (Argolis) and cipolin marbles (south Evia), whereas the highest values in limestones from Crete (25.1 vol.\%). Calcitic marbles display low water absorption values $(0.1 \mathrm{wt} . \%)$, with the highest values corresponding to limestones from Crete $(8.5 \mathrm{wt} . \%)$. Calcitic marbles and limestones from Magnesia and Crete respectively, display the lowest uniaxial compressive strength values (60 and $69 \mathrm{MPa}$, respectively), whereas dolomitic marbles from Drama display the highest values $(236 \mathrm{MPa})$. 
The lowest flexural strength under concentrated load values are observed in dolomitic marbles from Drama (2.3 MPa), with the highest values (36.1 and 25.6 MPa) in limestone from Edessa and in some of the calcitic marbles (Magnesia region) and cipolin marbles (south Evia). Breaking load at dowel hole lowest values are seen in dolomitic marbles from Drama $(900 \mathrm{~N})$, whereas the highest values from limestones in central Evia $(3000 \mathrm{~N})$ and dolomites in Viotia $(2850 \mathrm{~N})$. Abrasion resistance presents its lowest values in dolomites from Argolis $(7896 \mathrm{~mm})$ and its highest values $(30,859-33,003 \mathrm{~mm})$ in calcitic and dolomitic marbles from the region of Macedonia. The lowest rupture energy values (2 Joule) correspond to calcitic marbles from central Evia and some limestone types from Epirus (Ioannina), whereas the highest values (6 Joule) correspond to dolomitic marbles from Drama and cipolin marbles from south Evia. The frost resistance values determined are low in dolomitic marbles from Drama as well as limestones from Thesprotia (4.5 and $7 \mathrm{MPa}$, respectively), whereas the highest values are noticed in cipolin marbles from south Evia (24.4 MPa) and black limestone from Edessa (34.5 MPa).

\section{Discussion}

\subsection{Chemical Variations}

Results of this study show that the carbonate rock samples are characterized by element variability both in major and in trace elements. In order to shed light upon their behavior it is important to identify trends between selected elements, as displayed in the binary plots of Figure 5 . More specifically, $\mathrm{CaO}$ concentrations are negatively correlated with those of $\mathrm{MgO}$ (Figure $5 \mathrm{a}$ ), clearly distinguishing calciocarbonatites (calcitic marbles, cipollino marbles and limestones; calcite rich) from magnesiocarbonatites (dolomitic marbles and dolomites; dolomite-bearing or -rich). The positive correlation between $\mathrm{Na}_{2} \mathrm{O}$ and $\mathrm{K}_{2} \mathrm{O}$ (Figure $5 \mathrm{~b}$ ) indicates that their values depend almost exclusively upon the presence of feldspars and to a lesser extent by phyllosilicate minerals (muscovite and biotite), which are mostly identified in marbles from the east Macedonia region. A positive trend is noticed for the $\mathrm{Al}_{2} \mathrm{O}_{3}$ and $\mathrm{Fe}_{2} \mathrm{O}_{3}$ t contents (Figure 5c). In general, it is observed that $\mathrm{SiO}_{2}$ increases along with the enrichment of $\mathrm{Al}_{2} \mathrm{O}_{3}$ and $\mathrm{Fe}_{2} \mathrm{O}_{3} \mathrm{t}$, as displayed in Figure 5 d,e. These three major element oxides are included in metasomatic mineral phases (epidote, pumpellyite and chlorite) that are most frequently found in the cipollino marbles. However, it should also be considered that the aforementioned element contents may be also dependent upon the presence of other mineral phases, even if present in rather small amounts. In particular, $\mathrm{SiO}_{2}$ and $\mathrm{Al}_{2} \mathrm{O}_{3}$ contents may be affected by the inclusion of feldspars and quartz, whereas $\mathrm{Fe}_{2} \mathrm{O}_{3}$ t tends to be higher in samples that include Fe-oxides. The occurrence of the accessory ilmenite within the cipollino marble samples likely contributes to their $\mathrm{Fe}_{2} \mathrm{O}_{3} \mathrm{t}, \mathrm{TiO}_{2}$ and $\mathrm{V}$ contents (Figure 5f,g); however, the positive correlation between $\mathrm{Al}_{2} \mathrm{O}_{3}$ and $\mathrm{V}$ (Figure $5 \mathrm{~h}$ ) suggests that $\mathrm{V}$ contents may also be associated with the modal composition of epidote. Regarding $\mathrm{Mn}$, it seems that cipollino marbles possess slightly higher values, most likely attributed to layers of mica and epidote crystals between calcitic crystals.

The linear increase of $\mathrm{Cr}$ along with that of $\mathrm{Ni}$ (Figure $\mathrm{5i}$ ) is clearly associated with the amount of chromite present within marble samples mainly from the regions of the Peloponnese and Thessaly (samples KM-2, P-4, P-9, TH-3 and TH-6). Ba is positively correlated with silica contents of the cipollino marbles (Figure 5j), suggesting that the increasing presence of secondary metasomatic minerals plays a significant role in the barium contents. All cipollino marbles are found to be enriched in $\mathrm{Cu}$ compared to the other types, especially the two green cipollino samples from Evia island. A dolomite sample from Evia (STE-13) is also enriched in $\mathrm{Cu}$ and other chalcophile elements such as As and $\mathrm{Zn}$. This enrichment is likely associated with circulating slab related fluids during the exhumation stages of metamorphic rocks that were emplaced on the Pelagonian platform [34]. Similar mechanisms can explain the observed enrichment in $\mathrm{Pb}$ and As in a few calcitic marble samples from Crete island (Chania). 

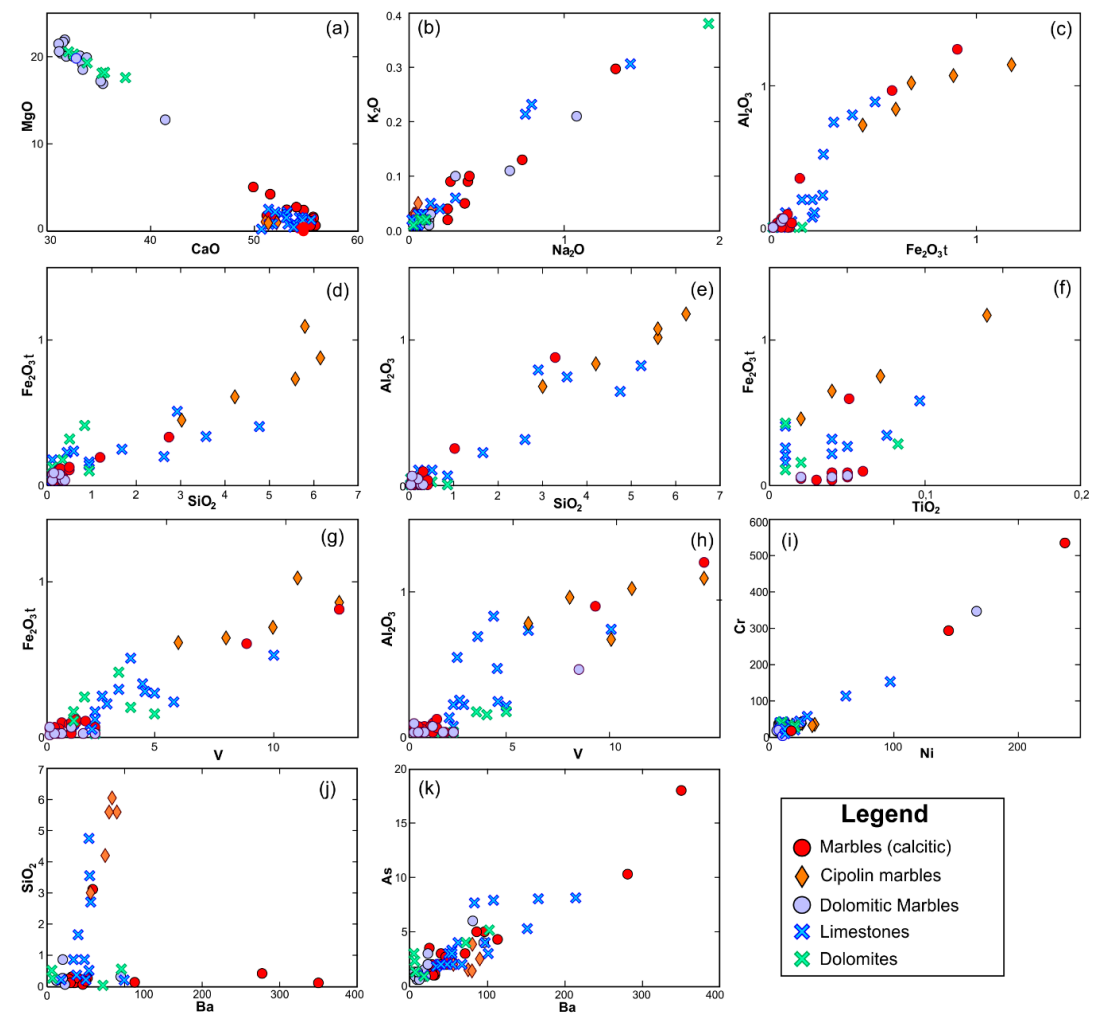

Figure 5. (a-k) Binary plots of selected major and trace elements, displaying their chemical behavior. Diagrams (b,k) are modified from Badouna et al., 2016 [14].

Marble samples tend to possess rather high Ba and notable As contents (Figure 5k), which are likely associated with transfer of few trace elements via circulation of metasomatic fluids, associated with oceanic metamorphism. Dolomites and dolomitic marbles tend to possess the lowest Ba and As contents. Sr tends to be higher in limestones and cipollino marbles compared to dolomitic rocks, since the $\mathrm{Sr}$ content decreases during dolomitisation and can also be used as diagenetic indicator $[35,36]$. Hence, Sr generally tends to decrease with increasing LOI contents. The Sr/Ca ratio in seawater, the sedimentation environment, and biogenic factors affect strontium separation in biogenic carbonates and control the $\mathrm{Sr} / \mathrm{Ca}$ ratio in marine carbonate rocks $[14,37,38]$. On the other hand, the higher $\mathrm{Sr}$ contents noticed in the cipollino marbles can be attributed to their contact with interlaying schists.

\subsection{Aesthetic and Physico-Mechanical Characteristics}

The aesthetic characteristics of carbonate ornamental stones rely on two main key factors that include specific textural features, as well as the colours reflected. The former can simply be related to crystal or even microfossil size distribution or testify to the metasomatic and metamorphic history, associated with deformation, foliation schistocity and vein-structured secondary infiltration phenomena. Colours on the other hand have a profound effect on the rock's appearance, strongly depending on its mineral assemblage, as well as its modal and chemical composition. Calcitic marbles of our study suite in most cases appear in varieties ranging from white- to grey-coloured. They predominantly include calcite, although grey-coloured calcitic marbles tend to possess slightly higher dolomite and accessory quartz and/or muscovite contents. Light red-coloured varieties are attributed to slight chemical impurities of calcite and more specifically to the substitution of $\mathrm{Ca}$ and $\mathrm{Mg}$ by Fe and $\mathrm{Mn}$, respectively.

Impure cipollino marbles commonly display green colours, but may also include zones with different colours. The predominant green colour is attributed to the relatively high amounts of metasomatic chlorite and pumpellyite, whereas brown-coloured zones are enriched in minerals that include epidote, mica and titanite. Less frequent are the blue-coloured zones, which include rather 
high amounts of Fe-rich chlorite, as well as the red-coloured zones that are enhanced by the presence of hematite and Fe-oxide veins. The macroscopic aesthetic appearance of the cipollino marbles are highly affected by the mineralogical composition, grain size, but also the metamorphic and metasomatic grade. Their commercial benefits strongly rely on the type of deformation and foliation, resulting in unique elliptical, banded and wavy structures as a result of significant tectonic processes.

Dolomitic marbles commonly vary between white to grey, whereas other less common varieties include yellow/light brown- and mixed-coloured varieties. The colours mostly depend upon the calcite/dolomite ratio and on the amount and type of accessory opaque minerals. Light brown varieties are attributed to the participation of clay minerals and limonite. The presence of slight chemical impurities in calcite and the occurrence of hematite, enhance red colours. Mixed colored dolomitic marbles consist of higher amounts of clay minerals, as well as of Fe-oxides and hydroxides (hematite, magnetite, limonite), often developing zones of different colour.

The Greek limestones in nature are usually white- or grey-coloured, consisting almost exclusively of calcite. However, when used as ornamental stones other coloured varieties are often preferred. Colours that range between brown and yellow are enhanced by the participation of clay minerals, limonite and quartz. Red- and pink-coloured varieties can be attributed to the presence of hematite in variable amounts as well as to Fe-Mn cations within calcite. Dark grey- to black-coloured limestones are characterized from the relatively high amounts of bitumens. In dolomitic samples, white and light grey colours clearly depend upon the dolomite/calcite ratio, whereas light red-coloured aggregates, which are often found within whitish marbles, are associated with the presence of Fe-oxides.

Concerning results obtained from physico-mechanical tests, it is observed that the Mg-poor rocks (calcitic marbles, cipollino marbles and limestones) and the Mg-bearing rocks (dolomitic marbles and dolomites) form very strong negative correlations between open porosity and apparent density values (Figure 6a). The Mg-bearing rocks tend to display higher apparent density values compared to the $\mathrm{Mg}$-poor rocks, which can be interpreted by the fact that dolomite has a higher grain density $\left(2866 \mathrm{~kg} / \mathrm{m}^{3}\right)$ than calcite $\left(2709 \mathrm{~kg} / \mathrm{m}^{3}\right)[39,40]$. Metamorphic processes also seem to be related with increasing apparent density values, which is attributed to the fact that recrystallization of the carbonate minerals in marbles tend to fill in the porous spaces that existed in limestones and dolomites but also increase the idiomorphic characteristics of the mineral constituents (Table 2). Regardless of their $\mathrm{Mg}$ content, open porosity values exhibit a very strong positive correlation with the measured water absorption values (Figure 6b). From both of the aforementioned binary plots (Figure 6a,b), it is observed that white-, grey- and green-coloured rocks (Mg-poor and Mg-bearing rocks) tend to display lower open porosity and water absorption values, as well as higher apparent density values, compared to rocks with different colours. The vast majority of the uniaxial compressive strength values range between 85-208 MPa (see Table S2). According to recommendations by the International Society for Rock Mechanics [41], these results correspond to strong and very strong rocks (Grade R5) that require many blows of a geological hammer to cause any fracture.

Breaking load (at dowel hole) values are strongly positively correlated with the flexural strength (under concentrated load) (Figure 6d). Some of the samples from our study suite (e.g., calcitic marbles from Magnesia, cipolin marbles and limestones from Evia, dolomitic marbles from Drama and dolomites from Viotia) exhibit rather high values of the aforementioned parameters and, therefore, are expected to have a low degree of bowing [42]. This is further supported by their relatively low open porosity values, which are also associated with the degree of bowing [43-46]. It should be noted that brown, red and green coloured varieties, almost exclusively display high values of the aforementioned parameters. The frost resistance values, determined after 48 test cycles, form very strong negative correlations with the flexural strength (under concentrated load) values (Figure 6d). These parameters are high for calcitic marbles from Magnesia region, cipolin marbles and limestones from Evia and dolomites from Viotia, which considerably reduces the potential of breaking. Based upon the petrographic observations, these samples are characterized by their rather small-sized calcite and 
dolomite grains, as well as by their low porosity. Both of these factors seem to be closely associated with high levels of frost resistance and flexural strength [47-50].
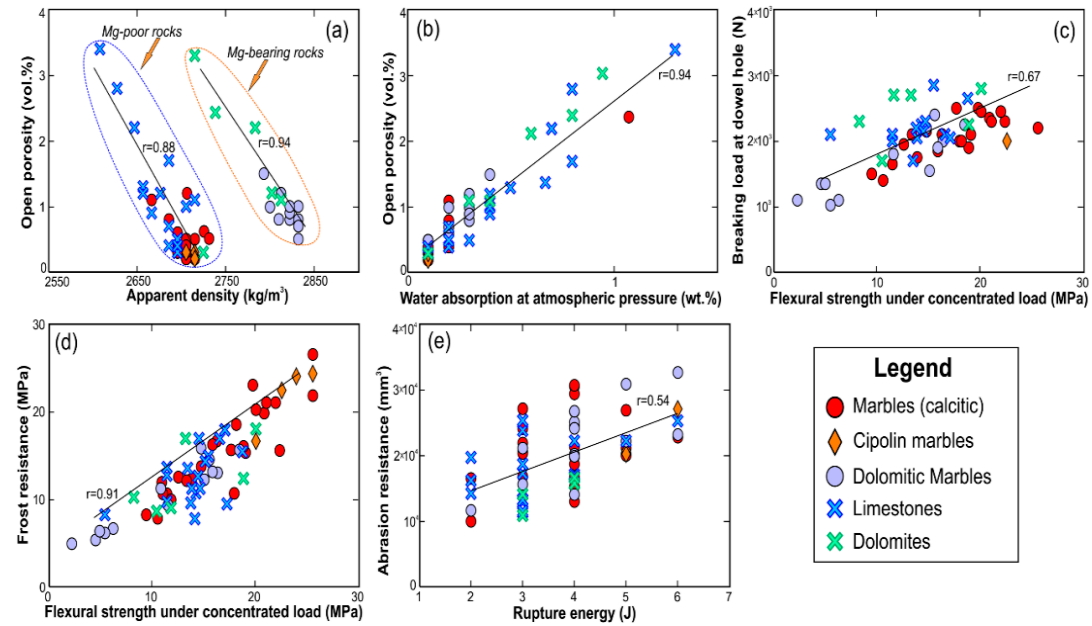

\begin{tabular}{|l|}
\hline \multicolumn{1}{|c|}{ Legend } \\
Marbles (calcitic) \\
$\checkmark$ Cipolin marbles \\
Dolomitic Marbles \\
$\chi$ Limestones \\
$x$ Dolomites \\
\hline
\end{tabular}

Figure 6. Binary diagrams of selected physico-mechanical properties: (a)Apparent density-Open porosity, (b) Water absorption at atmospheric pressure-Open porosity, (c) Flexural strength under concentrated load-Breaking load at dowel hole, (d) Flexural strength under concentrated load-Frost Resistance, (e) Rupture energy-Abrasion Resistance. The regression lines (solid) and the correlation coefficient (r) values are also given.

Table 2. Simplified table including average $\mathrm{CaO} / \mathrm{MgO}$ ratios, mineralogical, geochemical and physico-mechanical properties for every type of rock along with their standard deviation (from Tables S1 and S2) of the 73 selected Greek carbonate ornamental stone samples.

\begin{tabular}{|c|c|c|c|c|c|c|c|c|c|c|}
\hline Rock Type & \multicolumn{2}{|c|}{ Calcitic Marbles } & \multicolumn{2}{|c|}{ Cipollino Marbles } & \multicolumn{2}{|c|}{ Dolomitic Marbles } & \multicolumn{2}{|c|}{ Limestones } & \multicolumn{2}{|c|}{ Dolomites } \\
\hline $\begin{array}{l}\text { Main mineral } \\
\text { phases }\end{array}$ & \multicolumn{2}{|c|}{$\begin{array}{c}\text { cal (77-100 vol. \%), dol } \\
\text { (0-23 vol. \%) }\end{array}$} & \multicolumn{2}{|c|}{$\begin{array}{c}\text { cal (78-87 vol.\%), ep, } \\
\text { pmp, chl, qtz (<18 vol. } \%)\end{array}$} & \multicolumn{2}{|c|}{$\begin{array}{c}\text { cal (3-37 vol.\%), dol } \\
\text { (63-97 vol.\%) }\end{array}$} & \multicolumn{2}{|c|}{$\begin{array}{l}\text { cal( } 90-98 \text { vol. } \%), \text { dol } \\
\quad(2-10 \text { vol. } \%)\end{array}$} & \multicolumn{2}{|c|}{$\begin{array}{l}\text { dol (81-94 vol. \%), } \\
\text { cal (6-19 vol. \%) }\end{array}$} \\
\hline $\begin{array}{l}\text { Accessory } \\
\text { minerals }\end{array}$ & \multicolumn{2}{|c|}{$\begin{array}{l}\text { Mag, hem, chr, brt, clay } \\
\text { min., ms, bt, ser, ab, qtz, ep }\end{array}$} & \multicolumn{2}{|c|}{$\begin{array}{l}\mathrm{Ilm}, \mathrm{mag}, \text { hem, chr), ms, } \\
\text { bt, ttn, rt, ap, zrn, tur }\end{array}$} & \multicolumn{2}{|c|}{$\begin{array}{l}\text { Fe-oxides, fl, sp, chr, } \\
\text { qtz, chl, ms }\end{array}$} & \multicolumn{2}{|c|}{$\begin{array}{l}\text { clay min., qtz, ap, Fe-Mn } \\
\text { and Fe-Cr oxides }\end{array}$} & \multicolumn{2}{|c|}{$\begin{array}{l}\text { qtz, fsp, Fe-Mn } \\
\text { oxides }\end{array}$} \\
\hline & Avg. & $\pm(1 \sigma)$ & Avg. & $\pm(1 \sigma)$ & Avg. & $\pm(1 \sigma)$ & Avg. & $\pm(1 \sigma)$ & Avg. & $\pm(1 \sigma)$ \\
\hline $\mathrm{CaO} / \mathrm{MgO}$ & 387.66 & 1110.08 & 61.06 & 16.06 & 1.75 & 0.36 & 113.97 & 209.55 & 1.83 & 0.22 \\
\hline LOI & 42.63 & 1.87 & 40.52 & 0.87 & 45.79 & 0.78 & 41.97 & 3.49 & 45.74 & 1.14 \\
\hline $\mathrm{SiO}_{2}$ & 1.10 & 3.66 & 4.89 & 1.27 & 0.09 & 0.14 & 2.50 & 6.28 & 0.32 & 0.32 \\
\hline $\mathrm{Na}_{2} \mathrm{O}+\mathrm{K}_{2} \mathrm{O}$ & 0.43 & 0.48 & 0.41 & 0.70 & 0.27 & 0.36 & 0.47 & 0.61 & 0.82 & 0.78 \\
\hline $\mathrm{Al}_{2} \mathrm{O}_{3}$ & 0.27 & 0.58 & 1.01 & 0.26 & 0.04 & 0.10 & 0.34 & 0.42 & 0.05 & 0.04 \\
\hline $\mathrm{Fe}_{2} \mathrm{O}_{3 \mathrm{t}}$ & 0.10 & 0.18 & 0.73 & 0.27 & 0.02 & 0.03 & 0.31 & 0.77 & 0.17 & 0.16 \\
\hline $\mathrm{Cr}$ & 37.55 & 109.24 & 78.00 & 121.33 & 43.14 & 88.38 & 26.71 & 29.97 & 25.00 & 5.93 \\
\hline $\mathrm{Ni}$ & 22.30 & 47.06 & 53.60 & 52.43 & 21.07 & 42.03 & 21.52 & 21.30 & 16.00 & 6.16 \\
\hline $\mathrm{Ba}$ & 129.22 & 327.59 & 75.80 & 12.42 & 365.38 & 1276.68 & 279.00 & 899.93 & 1027.33 & 2436.25 \\
\hline $\mathrm{Sr}$ & 152.65 & 63.22 & 475.20 & 60.62 & 60.21 & 49.09 & 342.38 & 229.18 & 131.50 & 99.07 \\
\hline V & 2.81 & 5.72 & 10.00 & 3.39 & 1.48 & 2.29 & 7.06 & 15.77 & 2.87 & 1.53 \\
\hline As & 4.48 & 6.91 & 2.28 & 1.06 & 2.51 & 2.63 & 16.33 & 57.49 & 63.58 & 150.12 \\
\hline (1) & 2709.64 & 15.94 & 2715.00 & 5.77 & 2826.15 & 15.02 & 2648.50 & 148.69 & 2768.33 & 43.55 \\
\hline (2) & 0.45 & 0.26 & 0.28 & 0.05 & 0.91 & 0.28 & 2.38 & 5.42 & 1.73 & 1.09 \\
\hline (3) & 0.16 & 0.20 & 0.10 & 0.00 & 0.26 & 0.08 & 0.84 & 1.83 & 0.52 & 0.31 \\
\hline (4) & 107.00 & 21.88 & 86.00 & 0.00 & 178.23 & 33.98 & 142.38 & 34.01 & 144.33 & 27.22 \\
\hline (5) & 16.88 & 4.72 & 23.08 & 2.33 & 10.96 & 5.53 & 15.14 & 5.67 & 13.83 & 4.71 \\
\hline (6) & 2071.43 & 318.03 & 2000.00 & 0.00 & 1633.33 & 524.55 & 2210.00 & 301.31 & 2483.33 & 490.58 \\
\hline (7) & $21,313.16$ & 5410.02 & $22,309.00$ & 2927.87 & $22,088.00$ & 6283.16 & $17,563.30$ & 5328.10 & $13,227.00$ & 3388.43 \\
\hline (8) & 3.84 & 0.94 & 5.00 & 0.82 & 4.15 & 1.14 & 3.35 & 1.04 & 3.50 & 0.55 \\
\hline (9) & 15.53 & 5.00 & 21.93 & 3.58 & 10.12 & 4.38 & 13.24 & 6.14 & 12.48 & 4.08 \\
\hline
\end{tabular}

Notes: (1): Apparent density (kg/m³) (EN1936:2006), (2): Open porosity (vol.\%) (EN1936:2006), (3): Water absorption at atmospheric pressure (wt.\%) (EN13755:2005), (4): Uniaxial compressive strength (MPa) (EN1926:2006), (5): Flexural strength under concentrated load (MPa) (EN12372:2006), (6): Breaking load at dowel hole (N) (EN13364:2002), (7): Abrasion resistance ( $\mathrm{mm}^{3}$ - loss in volume) (EN14157:2017—method B), (8): Rupture energy (J) (EN14158:2004), (9): Frost resistance (MPa-tested after 48 frost resistance cycles) (EN12371:2010 and EN12372:2006), Ab: Albite, Ap: Apatite, Brt: barite, Bt: Biotite, Chl: Chlorite, Ep: Epidote, Fl: Fluorite, Fsp: Feldspar, Hem: Hematite, Ilm: Ilmenite, Mag: Magnetite, Ms: Muscovite, Qtz: Quartz, Rt: Rutile, Ser: Sericite, Sp: Sphalerite, Ttn: Titanite (sphene), Tur: Turmaline, Zrn: Zircon. 
The majority of the samples tested display rupture energy values that range between four (4) and six (6), suggesting that they possess an extremely low breaking potential [48,51]. It should be noted that most of these rocks have been affected by metamorphic and recrystallization processes, displaying almost exclusively white and grey colours. Other rocks have a moderate breaking potential (mostly limestones) and only very few can be considered as susceptible to breaking and/or cracking. As noticed in Figure 6e, rupture energy values exhibit a weak positive correlation with the abrasion resistance (loss in volume) values. The smaller determined values of the latter indicate a higher resistance to abrasion, which should be considered especially if the rocks will be used as paving materials to avoid slipping. Samples from our study suite display good abrasion behaviour, since the abrasion resistance values have an average a loss in volume of $\sim 19,500 \mathrm{~mm}^{3}$ (Table 2 and Table S2).

\section{Conclusions}

Commercial benefits of carbonate ornamental stones are highly dependent upon their aesthetic and physico-mechanical characteristics. Their chemistry, physico-mechanical properties and aesthetic characteristics are closely associated with their mineral assemblages, their modal composition, as well as the type and degree of diagenetic, metasomatic, metamorphic and deformation processes, including the extent and type of fluid circulation.

Based upon their $\mathrm{CaO} / \mathrm{MgO}$ ratios, their mineralogical, and geochemical properties (Table 2) the Greek carbonate ornamental stones are roughly divided into Ca-carbonates (calcitic marbles, cipollino marbles and limestones) and $\mathrm{Mg}$-carbonates (dolomitic marbles and dolomites). Apart from the predominant occurrence of calcite and dolomite, they often include accessory amounts of feldspars, phyllosilicates, epidote-group minerals and quartz, variably contributing on the overall geochemical features. Cipollino marbles tend to be enriched in the aforementioned major elements, as well as in $\mathrm{Fe}_{2} \mathrm{O}_{3} \mathrm{t}$ and $\mathrm{Cu}$. Other trace elements such as $\mathrm{Cr}$ and $\mathrm{Ni}$ are clearly enriched with increasing modal composition percentage of chromite crystals. $\mathrm{Ba}$, As and $\mathrm{Sr}$ contents are enhanced in cases where minerals that constitute the metasomatic association are present in higher amounts; and thus these elements are significantly affected by fluid circulation processes during oceanic metamorphism.

Regardless of the carbonate rock type, white to grey colours are indicative of the predominance of calcite and dolomite, but also for the minor presence of feldspars. Reddish colours are assigned to the inclusion of Fe- and $\mathrm{Mn}$ - cations within calcite, as well as to the addition of hematite. Yellow and brown colours are often associated with increased participation of epidote, limonite, titanite and clay minerals. Green colours are mainly attributed to the presence of chlorite and pumpellyite crystals, whereas dark blue colours have been noticed in metasomatic zones with abundant Fe-rich chlorite. Dark gray and black colours occur less frequently and in most cases are assigned to high amounts of bitumens. Deformation results in the development of schistosity patterns, which is many cases may prove beneficial for the commercial value, provided that these do not possess any defects.

The physico-mechanical results from tests conducted in samples from our study suite demonstrate that the Greek carbonate ornamental stones and their by-products from quarrying tend to display high quality physico-mechanical properties that in some cases may be considered as a premium. In particular, among the calcitic marbles, those which stand out for their physico-mechanical properties are located in the regions of Magnesia (Central Greece), in Kavala and Kozani (West Macedonia) and in Veria (Central Macedonia). Although not widely exposed in Greece, green-coloured cipolin marbles with very good physico-mechanical features are located in the southern parts of the island of Evia (Central Greece).

Ornamental stones and corresponding aggregates from limestones of high quality are positioned in the regions of Agios Kirillos (Crete island), in Central Evia island, in Etoloakarnania (Central Greece) and in Edessa (Central Macedonia). Regarding the latter case, the silica-bearing black limestone of Edessa $\left(\mathrm{SiO}_{2} \approx 28.0 \%\right)$ shows the highest values of flexural strength and frost resistance amongst all ornamental rock types considered in our study. Mg-bearing ornamental rocks with noteworthy physico-mechanical features include the dolomitic marbles located in Drama (East Macedonia) and 
Thasos island (North Aegean), along with dolomites located in Argolis (Peloponnese) and Viotia (Central Greece).

Supplementary Materials: The following are available online at http://www.mdpi.com/2075-163X/10/6/507/s1: Table S1: Whole rock major elements (wt.\%) and trace elements (ppm) compositions of carbonate ornamental stones from selected regions in Greece, Table S2: Physico-mechanical properties of the ornamental stone samples from selected regions in Greece. The testing methods were conducted according to EN Standards.

Author Contributions: Formal analysis, I.B., P.K. and C.K.; Investigation, I.B., K.L., M.P. and C.P.; Methodology, I.B., P.K., K.L. and M.P.; Supervision, I.B. and P.K.; Writing-original draft, I.B., P.K., C.K., K.L., N.K., P.T., M.P. and C.P.; Writing-Review and Editing, P.P. All authors have read and agreed to the published version of the manuscript.

Funding: This research received no external funding.

Acknowledgments: We would like to express our sincerest thanks to the four anonymous reviewers, and to the Editor for their constructive reviews, suggestions, and critical comments, which significantly helped improve this paper. The authors would also like to express their sincerest appreciation to the staff members George Economou, Yiannis Kouseris, Nikos Xirokostas, Pantelis Patsis and Michalis Sakalis of the Hellenic Survey for Geology and Mineral Exploration for their laboratory support at the Mineral Natural Resources Department.

Conflicts of Interest: The authors declare no conflict of interest.

\section{References}

1. Newman, H.R. The Mineral industry of Greece. In 2008 Minerals Yearbook Greece; USGS: Reston, VA, USA, 2008.

2. Charalampides, G.; Arvanitidis, N.; Vatalis, K.I.; Platias, S. Sustainability Perspectives in Greece as Reflected by Mineral Deposits Exploitation. Procedia Econ. Financ. 2013, 5, 143-151. [CrossRef]

3. Charalampides, G.; Vatalis, K.I.; Platias, S.; Karayannis, V. The Contribution of Industrial Minerals to Sustainable Recovery of Greek Economy. Procedia Econ. Financ. 2014, 14, 128-136.

4. Dolley, T.P. U.S Geological Survey Minerals Yearbook; Stone, Dimension; USGS: Reston, VA, USA, 2017; pp. 72.1-72.13, Advance Release.

5. Hastorun, S. The Mineral Industry of Greece. In 2014 Minerals Yearbook; USGS: Reston, VA, USA, 2017; pp. 19.1-19.10.

6. IOBE (Foundation for Economic \& Industrial Research). The contribution of the mining industry to the Greek economy. In Executive Summary; IOBE: Athina, Greece, 2016.

7. Eurostat, StoneNews.eu, First Half 2018-2019. Finished Marble Products Export Growth: The cases of Italy, Spain, Greece and Portugal. Available online: https://stonenews.eu/first-half-2018-2019-finished-marbleproducts-export-growth-cases-italy-spain-greece-portugal/ (accessed on 27 November 2019).

8. Sousa, L.M. Petrophysical properties and durability of granites employed as building stone: A comprehensive evaluation. B Eng. Geol. Environ. 2014, 73, 569-588. [CrossRef]

9. Calvo, J.P.; Regueiro, M. Carbonate rocks in the Mediterranean region-From classical to innovative uses of building stone. Geol. Soc. Spec. Publ. 2010, 331, 27-35. [CrossRef]

10. Munyanyiwa, H.; Hanson, R. Geochemistry of marbles and calc-silicate rocks in the Pan-African Zambezi belt, Zambia. Precambrian Res. 1988, 38, 177-200. [CrossRef]

11. Papatrechas, C. Correlation of Physicomechanical Properties with Grain Size and Mineralogical Composition of the Carbonate Rocks of Eastern Macedonia (Greece). Ph.D. Thesis, Department of Geology, University of Thessaloniki, Thessaloniki, Greece, 2011. (In Greek)

12. Ferrini, V.; De Vito, C.; Mignardi, S.; Fucinese, D. Archaeological carved slabs of the Langobard art in churches of Peligna Valley and Spoleto (Italy): Provenance of the stones. J. Archaeol. Sci. 2012, 39, 3505-3515. [CrossRef]

13. Brilli, M.; Giustini, F.; Conte, A.; Mercadal, P.; Quarta, G.; Plumed, H.; Scardozzi, G.; Belardi, G. Petrography, geochemistry, and cathodoluminescence of ancient white marble from quarries in the southern Phrygia and northern Caria regions of Turkey: Considerations on provenance discrimination. J. Archaeol. Sci. Rep. 2015, 4, 124-142.

14. Badouna, I.; Koutsovitis, P.; Laskaridis, K.; Patronis, M.; Papatrechas, C. Aesthetic characteristics of Greek ornamental stones associated with mineral, geochemical and structural properties. Bull. Geol. Soc. Greece 2016, 50, 1771-1780. [CrossRef]

15. Sabatakakis, N.; Koukis, G.; Tsiambaos, G.; Papanakli, S. Index properties and strength variation controlled by microstructure for sedimentary rocks. Eng. Geol. 2008, 97, 80-90. [CrossRef] 
16. Galetakis, M.; Soultana, A. A review on the utilisation of quarry and ornamental stone industry fine by-products in the construction sector. Constr. Build. Mater. 2016, 102, 769-781.

17. Petrounias, P.; Giannakopoulou, P.; Rogkala, A.; Lampropoulou, P.; Tsikouras, B.; Rigopoulos, I.; Hatzipanagiotou, K. Petrographic and Mechanical Characteristics of Concrete Produced by Different Type of Recycled Materials. Geosciences 2019, 9, 264. [CrossRef]

18. Yasar, E.; Erdogan, Y.; Kılıç, A. Effect of limestone aggregate type and water-cement ratio on concrete strength. Mater. Lett. 2004, 58, 772-777. [CrossRef]

19. Petrounias, P.; Giannakopoulou, P.P.; Rogkala, A.; Kalpogiannaki, M.; Koutsovitis, P.; Damoulianou, M.-E.; Koukouzas, N. Petrographic Characteristics of Sandstones as a Basis to Evaluate Their Suitability in Construction and Energy Storage Applications. A Case Study from Klepa Nafpaktias (Central Western Greece). Energies 2020, 13, 1119.

20. Kore, S.D.; Vyas, A. Impact of marble waste as coarse aggregate on properties of lean cement concrete. Case Stud. Constr. Mater. 2016, 4, 85-92.

21. Hebhoub, H.; Aoun, H.; Belachia, M.; Houari, H.; Ghorbel, E. Use of waste marble aggregates in concrete. Constr. Build. Mater. 2011, 25, 1167-1171.

22. Petrounias, P.; Giannakopoulou, P.; Rogkala, A.; Stamatis, P.; Lampropoulou, P.; Tsikouras, B.; Hatzipanagiotou, K. The Effect of Petrographic Characteristics and Physico-Mechanical Properties of Aggregates on the Quality of Concrete. Minerals 2018, 8, 577. [CrossRef]

23. EN 1936. Natural stone test methods. In Determination of Real Density and Apparent Density, and of Total and Open POROSITY; CEN: Brussels, Belgium, 2006.

24. EN 13755. Natural Stone Test Methods-Determination of Water Absorption at Atmospheric Pressure; CEN: Brussels, Belgium, 2005.

25. EN 1926. Natural stone test methods. In Determination of Uniaxial Compressive Strength; CEN: Brussels, Belgium, 2006.

26. EN 12372. Natural stone test methods. In Determination of Flexural Strength under Concentrated Load; CEN: Brussels, Belgium, 2006.

27. EN 13364. Natural stone test methods. In Determination of the Breaking Load at Dowel Hole; CEN: Brussels, Belgium, 2002.

28. EN 14157. Natural stone test methods. In Determination of the Abrasion Resistance; CEN: Brussels, Belgium, 2017.

29. EN 14158. Natural stone test methods. In Determination of Rupture Energy; CEN: Brussels, Belgium, 2004.

30. EN 12371. Natural stone test methods. In Determination of Frost Resistance; CEN: Brussels, Belgium, 2010.

31. Arnoldi, C.; Azzaro, E.; Barbieri, M.; Tucci, P. Petrographic and geochemical features of the "Cipollino Verde" marble from the Apuan Alps (northern Tuscany, Italy) and archaeometric implications. Period. Mineral. 1999, 68, 145-162.

32. Katsikatsos, G. Geology of Greece; University of Patras: Patras, Greece, 1992; pp. 1-451.

33. Woolley, A.R.; Kempe, D.R.C. Carbonatites: Nomenclature, Average Chemical Compositions, and Element Distribution; Carbonatites: Genesis and Evolution; Bell, K., Ed.; Unwin Hyman: London, UK, 1989; pp. 1-14.

34. Koutsovitis, P. High-pressure subduction-related serpentinites and metarodingites from East Thessaly (Greece): Implications for their metamorphic, geochemical and geodynamic evolution in the Hellenic-Dinaric ophiolite context. Lithos 2017, 276, 122-145.

35. Shearman, D.J.; Shirmohammadi, N.H. Distribution of strontium in dedolomites from the French Jura. Nature 1969, 223, 606-608. [CrossRef]

36. Garde, A.A. Strontium geochemistry and carbon and oxygen isotopic compositions of lower Proterozoic dolomite and calcite marbles from the Marmoliric formation, West Greenland. Precambrian Res. 1979, 8 , 183-199. [CrossRef]

37. Stoll, H.M.; Schrag, D.P. Coccolith Sr/Ca as a new indicator of coccolithophorid calcification and growth rate. Geochem. Geophy. Geosy. 2001, 1, 1-24. [CrossRef]

38. Lau, K.V.; Maher, K.; Brown, S.T.; Jost, A.B.; Altiner, D.; DePaolo, D.J.; Eisenhauer, A.; Kelley, B.M.; Lehrmann, D.J.; Paytan, A.; et al. The influence of seawater carbonate chemistry, mineralogy, and diagenesis on calcium isotope variations in Lower-Middle Triassic carbonate rocks. Chem. Geol. 2017, 471, 13-77.

39. Hall, C.; Hamilton, A. Porosity-density relations in stone and brick materials. Mater. Struct. 2015, 48, 1265-1271. [CrossRef] 
40. Hall, C.; Hamilton, A. Porosities of building limestones: Using the solid density to assess data quality. Mater. Struct. 2016, 49, 3969-3979.

41. Ulusay, R.; Hudson, J.A. The Complete ISRM Suggested Methods for Rock Characterization, Testing and Monitoring; Springer: Berlin, Germany, 2007.

42. Siegesmund, S.; Ruedrich, J.; Koch, A. Marble bowing: Comparative studies of three different public building facades. Envron. Geol. 2008, 56, 473-494.

43. Vázquez, P.; Siegesmund, S.; Alonso, F.J. Bowing of dimensional granitic stones. Environ. Earth Sci. 2011, 63, 1603-1612. [CrossRef]

44. Koch, A.; Siegesmund, S. Bowing of marble panels: On-site damage analysis from the Oeconomicum building at Goettingen (Germany). Geol. Soc. Spec. Publ. 2002, 205, 299-314. [CrossRef]

45. Grelk, B.; Christiansen, C.; Schouenborg, B.; Malaga, K. Durability of Marble Cladding—A Comprehensive Literature Review. J. Astm Int. 2007, 4, 1-19.

46. Cross, S.L. Behind the Curtain: Mechanical Treatments for Bowed Marble Panels. Master's Thesis (Historic Preservation), University of Pennsylvania, Philadelphia, PA, USA, 2005; p. 24.

47. Sariisik, G. Determining performance of marble finished products on their usage areas by a new impact resistance test method. J. Test. Eval. 2012, 40, 945-951. [CrossRef]

48. Sariisik, G.; Ozkan, E.; Kundak, E.; Akdas, H. Classification of Parameters Affecting Impact Resistance of Natural Stones. J. Test. Eval. 2016, 44, 1650-1660. [CrossRef]

49. Noor-E-Khuda, S.; Albermani, F.; Veidt, M. Flexural Strength of Weathered Granites: Influence of Freeze and Thaw Cycles. Constr. Build. Mater. 2017, 156, 891-901. [CrossRef]

50. Bumanis, G.; Dembovska, L.; Korjakins, A.; Bajare, D. Applicability of freeze-thaw resistance testing methods for high strength concrete at extreme $-52.5^{\circ} \mathrm{C}$ and standard $-18{ }^{\circ} \mathrm{C}$ testing conditions. Case Stud. Constr. Mater. 2018, 8, 139-149.

51. Gaziev, E. Rupture energy evaluation for brittle materials. Int. J. Solids Struct. 2001, 38, 7681-7690. [CrossRef]

(C) 2020 by the authors. Licensee MDPI, Basel, Switzerland. This article is an open access article distributed under the terms and conditions of the Creative Commons Attribution (CC BY) license (http://creativecommons.org/licenses/by/4.0/). 